\title{
THE INFLUENCE OF MAGNETIC FIELDS ON THE GROWTH OF ESCHERICHIA COLI MICROORGANISMS
}

\author{
J. Vanags ${ }^{1}$, M. Sonck ${ }^{2}$, V. Pugachev ${ }^{3}$, \\ A. Priede ${ }^{4}$, Dz. Vavere ${ }^{5}$ \\ ${ }^{1}$ Biotechnical Center, JSC, \\ 27 Dzerbenes Str., LV-1006, Riga, LATVIA \\ ${ }^{2}$ Aalto University School of Science and Technology, \\ 1 Otakaari Str., FI-02150 Espoo, FINLAND \\ ${ }^{3}$ Institute of Physical Energetics, \\ 21 Aizkraukles Str., LV-1006, Riga, LATVIA \\ ${ }^{4}$ Latvian State Institute of Wood Chemistry, \\ 27 Dzerbenes Str., LV-1006, Riga, LATVIA, \\ ${ }^{5}$ Medical Center of Jugla \\ 2 Juglas Str., Riga, LV-1024, LATVIA
}

\begin{abstract}
The aim of this research was to study the influence of magnetic field on the growth of microorganisms. In our experiments this influence was tested using Escherichia coli strain BT21. The experiments were carried out in a shaker flask at different intensities of magnetic field. The application of magnetic drives and joints in the bioreactors imposes strong requirements on the hermetic sealing of the testing vessels, which is utterly important from the sterility point of view. Our experiments have convincingly shown that the magnetic influence results in higher growth rate of biomass. In addition, some indications have been obtained that as the magnetic strength exceeds a definite level its positive influence on the bacterial growth decreases.
\end{abstract}

\section{INTRODUCTION}

Mechanical joints in the mixing drives of bioreactors for growing microorganisms often present a risk of contamination for the fermentation [1]. In the literature only the minimum information could be found about the influence of magnetic fields on the growth of microorganisms, with conclusions which are not always equipollent $[2,3]$. At the same time, in the last years a definite progress has been observed in the development of permanent magnets - the extension of $\mathrm{NdFeB}$ magnets based on the rare-earth elements. Therefore, also the conditions have been created for the development of magnetic drives to be applied in biotechnology and in other branches (e.g., in the pharmaceutical industry) where sterile environment is required.

\section{MATERIALS AND METHODS}

The experiment consisted of four parts. In each part two flasks were used, both containing the growth medium and Escherichia coli strain BT 21. One of the 
flasks contained a magnet, whereas the other had either no magnet or a weaker magnet. The flasks were placed on a flask shaker with a metallic bed interacting with the magnets. The bacterial growth was monitored during the growing by measuring the optical density (OD) as the indicator of changes in the biomass, and the glucose uptake as a function of time. After each experiment, the OD readings from both flasks were compared. Finally, the differences observed in each experiment were compared with one another.

\section{Magnets}

In the experiments, permanent $28 \times 13 \times 6 \mathrm{~mm} \mathrm{NdFeB}$ magnets (length $\times$ width $\times$ height, respectively) were employed. The magnets had relatively high values of magnetic energy $\mathrm{W}_{\mathrm{m}}$ and magnetic induction (remanence) $\mathrm{B}_{\mathrm{r}}$. The magnetic intensity was varied by using different number of magnets $(2,4$ and 6). The magnetization of the magnets was oriented through the height. Before the experiments, the magnets were covered with stainless steel film (thickness $0.15 \mathrm{~mm}$ ). The magnetic induction $\mathrm{B}_{\mathrm{r}}$ was measured in the middle point of the outer surface. In the measurements, a Gaussmeter 410 (Brockhaus Messtechnik) was used. For separate magnets the $\mathrm{B}_{\mathrm{r}}$ value was in the range $0.21-0.23 \mathrm{~T}$.

In Table 1, the characteristics of the magnets are presented.

Table 1

The number, shape and flux density of the magnets

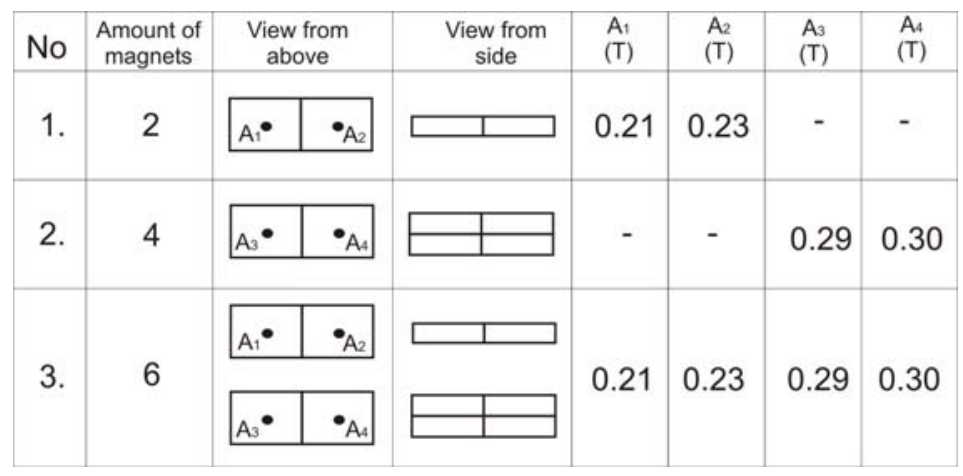

The number of magnets placed in the flasks used in each experiment is given in Table2.

The number of magnets in the experimental flasks

\begin{tabular}{|c|c|c|}
\hline \multirow{2}{*}{ Experiment } & \multicolumn{2}{|c|}{ Number of magnets } \\
\cline { 2 - 3 } & Flask 1 & Flask 2 \\
\hline 1 & 4 & 0 \\
\hline 2 & 4 & 2 \\
\hline 3 & 6 & 0 \\
\hline 4 & 2 & 0 \\
\hline
\end{tabular}


Accordingly, the experiments are referred to as $4 / 0,4 / 2,6 / 0$ and 2/0.

\section{Preparation of the seed material}

The preparation of the seed material proceeded as follows (see Appendix). The medium was diluted in sterilized water to a final volume of $100 \mathrm{ml}$, with $5 \mathrm{ml}$ of this amount added into 10 test tubes. Into each tube, $0.5 \mathrm{ml}$ of the medium containing E. coli strain BT-21 (OD 1.12 at $560 \mathrm{~nm}$ ) was added. The tubes were incubated overnight $\left(16 \mathrm{~h}, 37^{\circ} \mathrm{C}\right)$ and kept in a refrigerator until the tests.

\section{Preparation of the growth media}

The growth media for each experiment were prepared according to Appendix. However, in order to achieve the growth conditions in the parallel flasks as similar as possible, the growth media for both the flasks were prepared together and then divided between the flasks. The medium was diluted in sterilized water to the volume of $192 \mathrm{ml}$. The $\mathrm{pH}$ was adjusted to 7 by adding $0.4 \mathrm{ml}$ of $\mathrm{NaOH}$. With $8 \mathrm{ml}$ of the E. coli seed material added, the total volume reached $200 \mathrm{ml}$. The solution was then divided between the two flasks.

\section{The growing and the measurements}

The flasks were placed into an ES-20 (Biosan) incubator, at $37{ }^{\circ} \mathrm{C}$ and $180 \mathrm{rpm}$. In order to minimize the effect of the magnets' cross-influence between the flasks, these were positioned as far from each other as possible. Before placing the flasks into the incubator, their initial OD was measured with a Helios spectrophotometer (ThermoSpectronic), and the initial glucose concentration with an Accu-Check Active glucose test meter (Roche). During the growing, the OD was measured every hour, and the glucose concentration every three hours.

\section{RESULTS}

The results of OD and glucose concentration measurements for each experiment are shown in Figs. 1-4 in a graphical form.

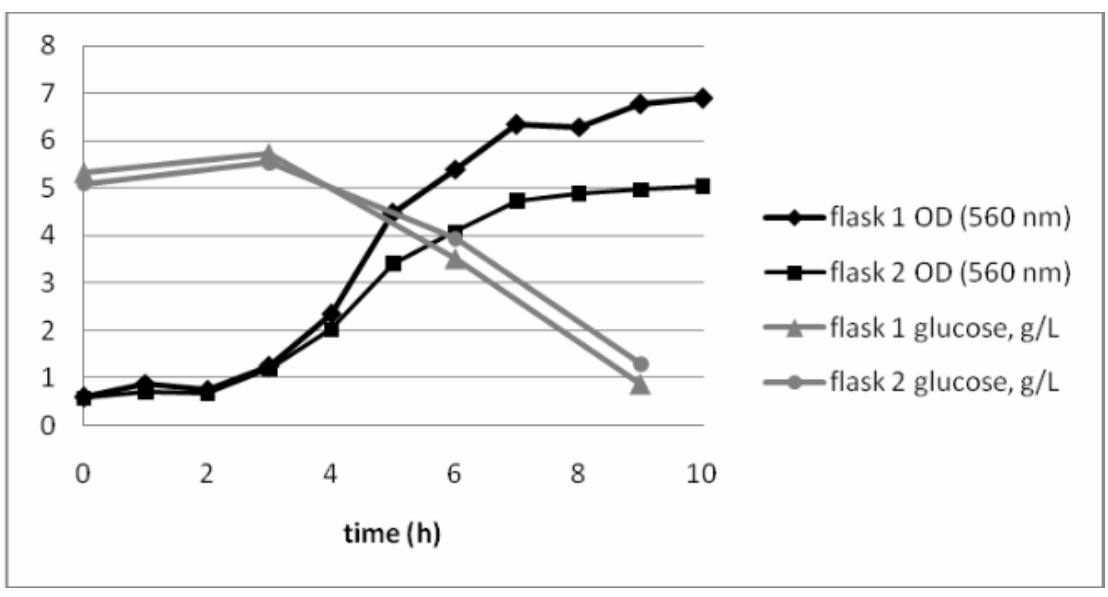

Fig. 1. Time dependences of the OD and glucose concentration during experiment 4/0. 


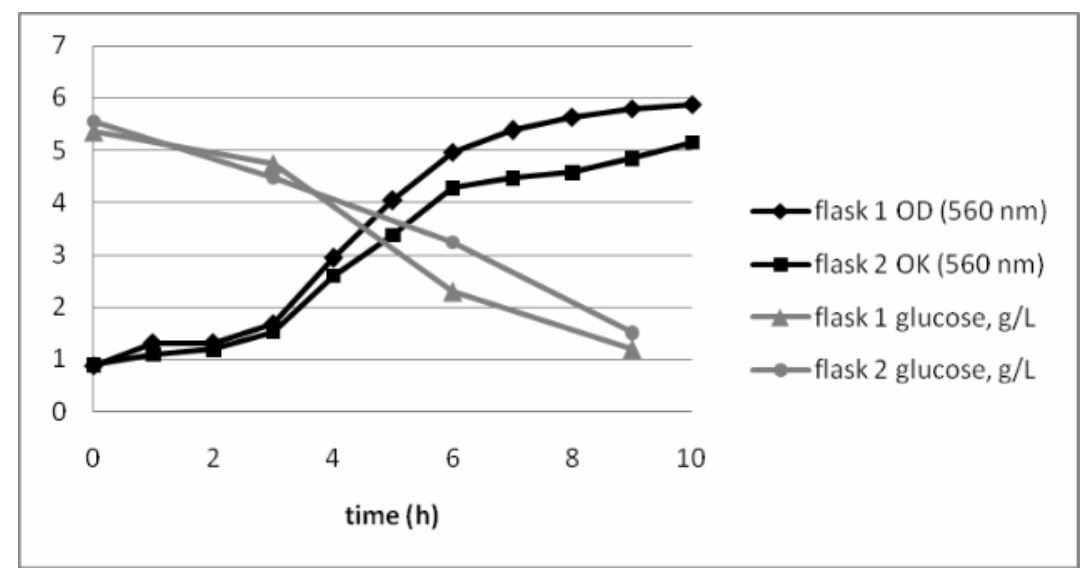

Fig. 2. Time dependences of the OD and glucose concentration during experiment 4/2.

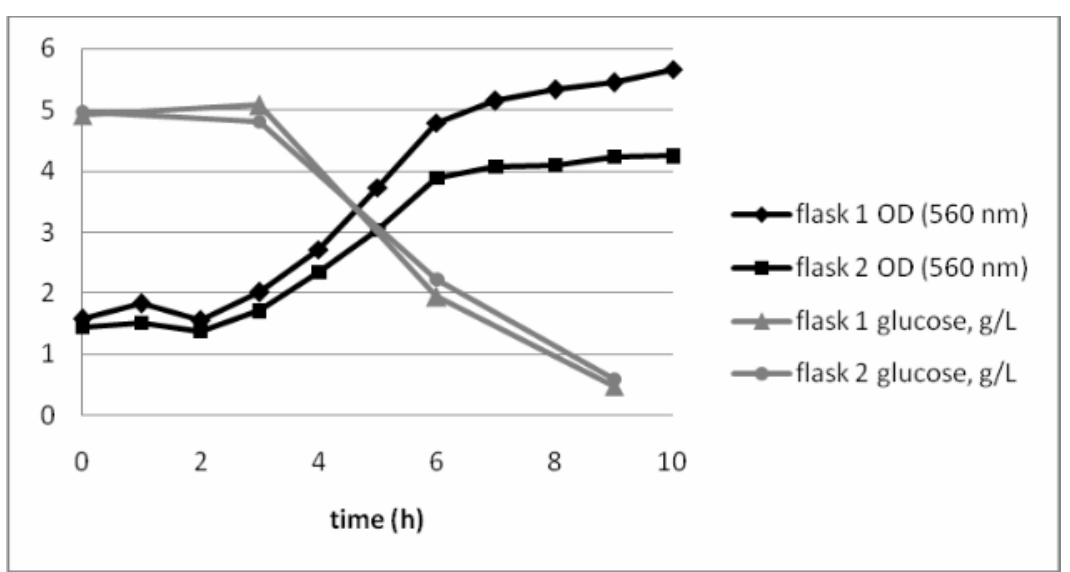

Fig. 3. Time dependences of the OD and glucose concentration during experiment 6/0.

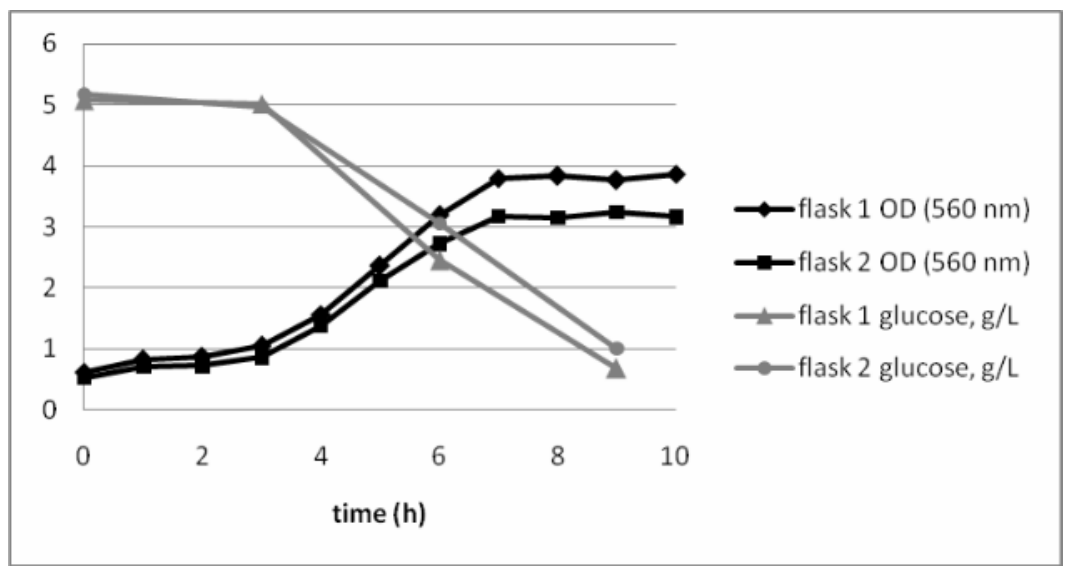

Fig. 4. Time dependences of the OD and glucose concentration during experiment 2/0.

Figures 1 to 4 show that practically in each case the OD readings from flask 1 are greater than those from flask 2.

From these figures it can be seen that during the exponential phase the differences between flask 1 and flask 2 increase, and then become more stable as 
the stationary phase is reached; the specific growth rates decrease, and the maximum biomass is thus reached.

All the experiments demonstrate a clear difference in the ODs between flask 1 and flask 2, resulting in approx. 15-35\%. In each experiment it is flask 1 (in which the bacteria are under a stronger magnetic influence) that reaches higher ODs.

In experiments $4 / 2$ and $2 / 0$, where the difference in the magnetic influence was less expressed, the difference between the biomass values was also smaller. This was so despite the fact that in experiment $2 / 0$ the flask 1 OD at the zero hour was noticeably greater than the flask $2 \mathrm{OD}$, which indicates that the initial conditions in these flasks were less homogeneous. On the other hand, the experiment $6 / 0$ appears to result in smaller differences than experiment $4 / 0$, indicating that the ideal magnetic strength might have been exceeded.

\section{CONCLUSIONS}

Our experiments have convincingly shown that the magnetic influence results in greater biomass build-up. The results also indicate lower OD (optical density) distinctions in the experiments where the difference between the magnetic field strengths was smaller. In addition, our results may provide suggestions as to the ideal strength of the magnetic field to be applied in magnetic drives and other biotechnological facilities. During the research, some indications have been obtained that with the magnetic strength exceeding a definite level its positive influence on the bacterial growth weakens. In order to obtain more precise information about the optimal magnetic strength we are planning further experiments.

\section{ACKNOWLEDGEMENTS}

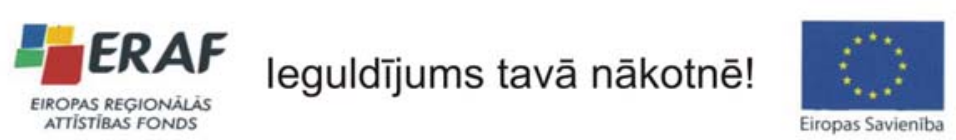

This work was supported by the EU Fund 2 in the framework of programme "Entrepreneurship and innovations", sub-activity 2.1.2.2.1 "Development of new products and technologies" (agreement Nr. L-JPI-09-0048 between the Latvian Agency of Investments \& Development and the Biotechnical Center (JSC)).

\section{REFERENCES}

1. Vanags, J., \& Viesturs, U. (2001). Local mixing intensity measurements for the food industry and biotechnology. Food Technology and Biotechnology 39 (1) 59-65.

2. Nasher, Samir. H., \& Hussein, Amal. A. (2008). Effect of magnetic field on the growth of Escherichia coli and Staphylococcus aureus. Eng.\&Tech., 26 (4).

3. Kazumasa Okuno, Koji Tuchiya, Takashi Ano, \& Makoto Shoda. (1993). Effect of super-high magnetic field on the growth of Escherichia coli under various medium compositions and temperatures. J. Fermentation and Bioengineering, 75 (2), 103-106. 


\section{Appendix}

Preparation of the components of the growth medium, their sterilization and amount on $100 \mathrm{ml}$ flask medium

\begin{tabular}{|c|c|c|c|c|c|c|}
\hline \multicolumn{7}{|c|}{ Media according to R. Bajpai } \\
\hline Nr. & Component & $\mathrm{g} / \mathrm{L}$ & $\begin{array}{l}\text { Measured } \\
\text { amount, g }\end{array}$ & $\begin{array}{c}\text { Dilution } \\
\text { with dist. } \\
\mathrm{H}_{2} \mathrm{O}\end{array}$ & $\begin{array}{l}\text { Sterilization } \\
\text { method }\end{array}$ & $\begin{array}{c}\text { Component } \\
\text { amount on } \\
100 \mathrm{ml} \\
\text { flask } \\
\text { medium }\end{array}$ \\
\hline 1. & glucose & 5 & 417.6 & 1000 & $\begin{array}{c}30 \mathrm{~min} .0 .5 \mathrm{~atm} . \\
110^{\circ} \mathrm{C}\end{array}$ & 1.20 \\
\hline 2. & $\left(\mathrm{NH}_{4}\right)_{2} \mathrm{SO}_{4}$ & 3.5 & 14 & 100 & $\begin{array}{c}30 \text { min. } 1 \mathrm{~atm} . \\
121^{\circ} \mathrm{C} \\
\end{array}$ & 2.50 \\
\hline 3. & $\mathrm{KH}_{2} \mathrm{PO}_{4}$ & 5.6 & 22.4 & \multirow{2}{*}{200} & $40 \mathrm{~min} .1 \mathrm{~atm}$. & \multirow{2}{*}{5.00} \\
\hline 4. & $\mathrm{~K}_{2} \mathrm{HPO}_{4}$ & 0.45 & 1.8 & & & \\
\hline 5. & $\mathrm{MgSO}_{4} \cdot 7 \mathrm{H}_{2} \mathrm{O}$ & 0.35 & 3.5 & 100 & $\begin{array}{c}40 \mathrm{~min} .1 \mathrm{~atm} . \\
121^{\circ} \mathrm{C} \\
\end{array}$ & 1 \\
\hline 6. & $\mathrm{CaCl}_{2} \cdot 2 \mathrm{H}_{2} \mathrm{O}$ & 0.003 & 3 & 100 & $\begin{array}{l}\text { filtration } \\
(0.2 \mu \mathrm{m})\end{array}$ & 0.01 \\
\hline 7. & $\mathrm{FeCl}_{3} \cdot 6 \mathrm{H}_{2} \mathrm{O}$ & 0.017 & 1.7 & 100 & $\begin{array}{l}\text { filtration } \\
(0.2 \mu \mathrm{m}) \\
\end{array}$ & 0.1 \\
\hline 8. & $\mathrm{Zn}\left(\mathrm{CH}_{3} \mathrm{COO}\right)_{2} \cdot 2 \mathrm{H}_{2} \mathrm{O}$ & 0.0065 & 6.5 & 100 & $\begin{array}{l}\text { filtration } \\
(0.2 \mu \mathrm{m}) \\
\end{array}$ & 0.01 \\
\hline 9. & $\mathrm{CoCl}_{2} \cdot 6 \mathrm{H}_{2} \mathrm{O}$ & 0.006 & 0.6 & 100 & $\begin{array}{l}\text { filtration } \\
(0.2 \mu \mathrm{m}) \\
\end{array}$ & 0.1 \\
\hline 10. & $\mathrm{Na}_{2} \mathrm{MoO}_{4} \cdot 2 \mathrm{H}_{2} \mathrm{O}$ & 0.006 & 0.6 & 100 & $\begin{array}{l}\text { filtration } \\
(0.2 \mu \mathrm{m}) \\
\end{array}$ & 0.1 \\
\hline 11. & $\mathrm{CuCl}_{2} \cdot 2 \mathrm{H}_{2} \mathrm{O}$ & 0.003 & 0.3 & 100 & $\begin{array}{l}\text { filtration } \\
(0.2 \mu \mathrm{m}) \\
\end{array}$ & 0.1 \\
\hline 12. & $\mathrm{H}_{3} \mathrm{BO}_{3}$ & 0.003 & 0.3 & 100 & $\begin{array}{l}\text { filtration } \\
(0.2 \mu \mathrm{m})\end{array}$ & 0.1 \\
\hline 13. & vitamin $\mathrm{B}_{1}$ & 0.01 & \multicolumn{3}{|c|}{ from ampoule ( $5 \%$ solution) } & 0.02 \\
\hline 14. & yeast extract & 5 & 20 & 100 & $\begin{array}{c}30 \text { min. } 0.6 \mathrm{~atm} . \\
115^{\circ} \mathrm{C}\end{array}$ & 2.5 \\
\hline
\end{tabular}

\section{MAGNĒTISKĀ LAUKA IETEKME UZ MIKROORGANISMA ESCHERICHIA COLI AUGŠANU}

J. Vanags, M. Sonks, V. Pugačevs, A. Priede, Dz. Vāvere

$$
\text { Kops a vilk m s }
$$

Dotā pētījuma mērksis bija izpētīt magnētiskā lauka ietekmi uz mikroorganismu augšanu. Šai sakarā mūsu eksperimentos tika testēta mikrooganismu kutūras Escherichia coli celms BT21 pie dažādām magnētiskā lauka intensitātēm, veicot kultivāciju kratītāja kolbās. Šāda informācija ir nozīmīga biotehnologisko iekārtu izveidē, jo, izmantojot magnētisko piedziṇu risinājumus, var sasniegt augstus sterilizācijas rādītājus bioreaktoros. Mūsu eksperimentos rezultāti konsekventi parādīja, ka līdz zināmai robežai magnētiskais lauks veicina mikroorganisma augšanas ātruma palielināšanos, tālāka magnētsikā lauka palielināšana vairāk nepalielināja biomasas pieaugumu.

20.9.2010. 